\title{
Animal foods, protein, calcium and prostate cancer risk: the European Prospective Investigation into Cancer and Nutrition
}

\begin{abstract}
NE Allen*,', TJ Key', PN Appleby', RC Travis', AW Roddam', A Tjønneland², NF Johnsen², K Overvad ${ }^{3}$, J Linseisen ${ }^{4}$, S Rohrmann ${ }^{4}$, H Boeing ${ }^{5}$, T Pischon ${ }^{5}$, HB Bueno-de-Mesquita ${ }^{6}$, L Kiemeney ${ }^{7,8}$, G Tagliabue ${ }^{9}$, D Palli ${ }^{10}$, P Vineis ${ }^{11,12}$, R Tumino ${ }^{13}$, A Trichopoulou ${ }^{14}$, C Kassapa ${ }^{14}$, D Trichopoulos ${ }^{15}$, E Ardanaz ${ }^{16}$, N Larrañaga ${ }^{17}$, M-J Tormo ${ }^{18}$, CA González ${ }^{19}$, JR Quirós ${ }^{20}$, M-J Sánchez ${ }^{21}$, S Bingham ${ }^{22}$, K-T Khaw ${ }^{23}$, J Manjer ${ }^{24}$, G Berglund $^{25}$, P Stattin ${ }^{26}$, G Hallmans ${ }^{27}$, N Slimani ${ }^{28}$, P Ferrari ${ }^{28}$, S Rinaldi ${ }^{28}$ and E Riboli ${ }^{12}$

'Cancer Epidemiology Unit, University of Oxford, Oxford, UK; ${ }^{2}$ Institute of Cancer Epidemiology, Danish Cancer Society, Copenhagen, Denmark; ${ }^{3}$ Department of Epidemiology and Social Medicine, University of Aarhus, Aarhus, Denmark; ${ }^{4}$ Division of Cancer Epidemiology, German Cancer Research Centre, Heidelberg, Germany; ${ }^{5}$ German Institute of Human Nutrition, Potsdam-Rehbücke, Germany; ${ }^{6}$ National Institute of Public Health and Environment, Bilthoven, The Netherlands; ${ }^{7}$ Department of Epidemiology, University Medical Centre, Nijmegen, The Netherlands; ${ }^{8}$ Department of Urology, University Medical Centre, Nijmegen, The Netherlands; ${ }^{\circ}$ Lombardy Cancer Registry Unit, National Cancer Institute, Milan, Italy; ${ }^{10}$ Molecular and Nutritional Epidemiology Unit, Scientific Institute of Tuscany, Florence, Italy; "Department of Biomedical Science, University of Turin, Turin, Italy; ${ }^{12}$ Department of Epidemiology and Public Health, Imperial College, London, UK; ${ }^{13}$ Cancer Registry, Azienda Ospedaliera Civile M.P. Arezzo, Ragusa, Italy; ${ }^{14}$ Department of Hygiene and Epidemiology, University of Athens Medical School, Athens, Greece; ${ }^{15}$ Hellenic Health Foundation, Athens, Greece; ${ }^{16}$ Seccion de Vigilancia y Control Epidemiologico, Instituto de Salud Publica de Navarra, Pamplona, Spain; ${ }^{17}$ Epidemiology Unit, Basque Health Department in Gipuzkoa, San Sebastian, Spain; ${ }^{18}$ Epidemiology Department, Murcia Health Council, Murcia, Spain; ${ }^{19}$ Catalan Institute of Oncology, Barcelona, Spain; ${ }^{20}$ Public Health and Health Planning Directorate, Asturias, Spain; ${ }^{21}$ Andalusian School of Public Health, Granada, Spain; ${ }^{22}$ MRC Centre for Nutritional Epidemiology in Cancer Prevention and Survival, Department of Public Health and Primary Care, Cambridge, UK; ${ }^{23}$ Department of Gerontology, University of Cambridge, Cambridge, UK; ${ }^{24}$ Department of Surgery, Malmö University Hospital, Lund University, Malmö, Sweden;

${ }^{25}$ Department of Clinical Sciences, Malmö University Hospital, Lund University, Malmö, Sweden; ${ }^{26}$ Division of Urology and Andrology, Department of Surgical and Perioperative Sciences, Umeå University Hospital, Umeå, Sweden; ${ }^{27}$ Department of Public Health and Clinical Medicine, Nutrition Research, Umeå University Hospital, Umeå, Sweden; ${ }^{28}$ Nutrition and Hormones Group, International Agency for Research on Cancer, Lyon, France
\end{abstract}

We examined consumption of animal foods, protein and calcium in relation to risk of prostate cancer among 142251 men in the European Prospective Investigation into Cancer and Nutrition. Associations were examined using Cox regression, stratified by recruitment centre and adjusted for height, weight, education, marital status and energy intake. After an average of 8.7 years of follow-up, there were 2727 incident cases of prostate cancer, of which I I 3 I were known to be localised and 54I advanced-stage disease. A high intake of dairy protein was associated with an increased risk, with a hazard ratio for the top versus the bottom fifth of intake of 1.22 (95\% confidence interval $(\mathrm{Cl})$ : 1.07-1.41, $\left.P_{\text {trend }}=0.02\right)$. After calibration to allow for measurement error, we estimated that a $35-\mathrm{g} \mathrm{day}^{-1}$ increase in consumption of dairy protein was associated with an increase in the risk of prostate cancer of $32 \%\left(95 \% \mathrm{Cl}: \mathrm{I}-72 \%, P_{\text {trend }}=0.04\right)$. Calcium from dairy products was also positively associated with risk, but not calcium from other foods. The results support the hypothesis that a high intake of protein or calcium from dairy products may increase the risk for prostate cancer.

British Journal of Cancer (2008) 98, 1574- I581. doi:I0.1038/sj.bjc.660433 I www.bjcancer.com

Published online I April 2008

(c) 2008 Cancer Research UK

Keywords: prostate cancer; dairy protein; calcium; prospective; EPIC

Little is known about the aetiology of prostate cancer. It has been suggested that a high intake of animal protein might increase the incidence of prostate cancer by enhancing growth hormone activity (Sato, 1963). Ecological studies have shown that milk intake is strongly correlated with both incidence and mortality

* Correspondence: Dr NE Allen, Cancer Epidemiology Unit, University of Oxford, Oxford OX3 7LF, UK;

E-mail: naomi.allen@ceu.ox.ac.uk

Received 17 December 2007; revised 4 February 2008; accepted 4 February 2008; published online I April 2008 from prostate cancer (Ganmaa et al, 2002; Colli and Colli, 2006). It has been hypothesised that a high intake of dairy protein may increase prostate cancer risk by increasing the production of insulin-like growth-factor-I (IGF-I), which in turn may promote development of prostate cancer (Renehan et al, 2004; Allen et al, 2007). An alternative hypothesis is that a high intake of calcium, primarily from dairy products, may increase risk by suppressing the synthesis of 1,25-dihydroxyvitamin D (Giovannucci, 1998).

In the present study, we investigated prostate cancer risk in relation to consumption of animal foods, protein and calcium among 142520 men in the European Prospective Investigation into Cancer and Nutrition (EPIC). 


\section{MATERIALS AND METHODS}

The European Prospective Investigation into Cancer and Nutrition is a multicentre prospective study designed to investigate the relationships between diet, lifestyle, environmental factors and cancer. The methods of recruitment and study design are fully described elsewhere (Riboli et al, 2002). The total cohort comprises approximately 500000 men and women recruited in 28 centres in 10 European countries: Denmark, France, Germany, Greece, Italy, the Netherlands, Norway, Spain, Sweden and the United Kingdom (UK). In this paper, we describe data for men from 19 centres in eight of these countries, no data being available for France or Norway because only women were recruited in these two countries. Men were recruited between 1989 and 2004, and the median age at recruitment was 52 years.

The men included in this analysis were recruited from the population of defined geographical areas in each of the eight countries (general population in most centres, blood donors in Ragusa and Turin in Italy and in the Spanish centres), except for most of those in the Oxford subcohort, who were recruited throughout the United Kingdom to enroll a large number of vegetarians. Study participants were almost all white Europeans. Eligible men were invited to participate in the study, and those who accepted gave informed consent and completed questionnaires on their diet, lifestyle and medical history. Approval for this study was obtained from the ethical review boards of the International Agency for Research on Cancer (IARC) and from local ethics committees in each country.

Men were not eligible for this analysis if they had previously been registered as having cancer at the time of completing the baseline questionnaire, if they had no dietary or nondietary data, or if they had missing dates of cancer diagnosis or follow-up. Individuals were also excluded if they were in the top or bottom $1 \%$ of the distribution of the ratio of reported energy intake to energy requirement, to reduce the impact of implausible extreme values in the analysis (Ferrari et al, 2002). Following these exclusions, complete data on diet and follow-up for cancer were available for 142520 men out of the 148372 men in the original data set.

Dietary intake during the year before enrolment was measured by country-specific validated food frequency questionnaires (FFQs) or diet histories, as previously described (Riboli et al, 2002). For this analysis, animal foods included total meat and meat products (and the subcategories red meat, poultry and processed meat), fish and shellfish (and the subcategories white fish and fatty fish), dairy products (and the subcategories milk and milk beverages, yoghurt and cheese) and eggs. Estimated daily nutrient intakes were calculated by multiplying the nutrient content of each food of a specific portion size by the frequency of consumption as stated on the FFQ using national food tables from each country. Greece and Umeå were not included in the analyses of animal, dairy or plant protein, or Greece in that of calcium intake, because the relevant data were not available.

The nondietary questions covered education and socioeconomic status, occupation, history of previous illness and disorders or surgical operations, lifetime history of consumption of tobacco and alcoholic beverages, and physical activity. Height and weight were measured at recruitment, except for most of the men in the Oxford cohort among whom height and weight were self-reported.

Follow-up is provided by population-based cancer registries in six of the participating countries: Denmark, Italy, the Netherlands, Spain, Sweden and the United Kingdom. In Germany and Greece, follow-up is via self-completed questionnaires, and self-reported incident cancers are verified through medical records. Data on vital status in most EPIC centres were collected from mortality registries at the regional or national level, in combination with data collected by active follow-up (Greece). By March 2007, complete follow-up data had been reported to IARC up to December 2003 or December 2004 for most centres. Follow-up was censored at the date of diagnosis of prostate cancer, or at the date of diagnosis of other cancers, death, emigration or end of follow-up, whichever came first. The 10th Revision of the International Statistical Classification of Diseases, Injuries and Causes of Death (ICD) was used, and cancer of the prostate as analysed here was defined as code C61.

Data on TNM stage and Gleason grade were collected from each centre, where possible. In all, 1672 cases (61\%) had information on stage and 1630 cases $(60 \%)$ had information on grade. Tumours were classified as localised (TNM staging score of T0/T1/T2 and $\mathrm{N} 0 / \mathrm{NX}$ and M0, or stage coded in the recruitment centre as localised; $n=1131$ ) or advanced (T3 or T4 or N1 + or M1, or stage coded in the recruitment centre as metastatic; $n=541$ ) or unknown. Subset analyses were also conducted for low-grade (Gleason sum $<7$ or equivalent (cases coded as well differentiated or moderately differentiated); $n=982$ ) and high-grade disease (Gleason sum $\geqslant 7$ or equivalent (cases coded as poorly differentiated or undifferentiated); $n=648$ ), or unknown.

\section{Statistical analyses}

Analyses of the associations of foods and nutrients and potential confounding factors with risk were conducted using Cox regression. Data were stratified by centre, and age was used as the underlying time scale in all models.

Food and nutrient intakes estimated from the dietary questionnaires (Riboli et al, 2002) were calculated in g day $^{-1}$, unless otherwise stated. Dietary intakes were primarily analysed as categorical variables, based on quintiles of the distribution among noncases across all EPIC centres combined. Tests for linear trend were conducted using continuous values for each food and nutrient variable; nutrient increments were set at $35 \mathrm{~g} \mathrm{day}^{-1}$ for all protein variables and $0.3 \mathrm{gday}^{-1}$ for all calcium variables (corresponding to approximately 1 s.d. in total protein and calcium intake, respectively) to make comparable assessments of intake with risk. All models were adjusted for educational level (no degree, degree or higher, unknown), marital status (married/ cohabiting, not married/cohabiting and unknown), height $(<170$, $170-174,175-179$ and $\geqslant 180 \mathrm{~cm})$, weight $(<70,70-79,80-89$ and $\geqslant 90 \mathrm{~kg}$ ) and energy intake (MJ day ${ }^{-1}$; continuous). Further adjustment for combined occupational and recreational physical activity (physically inactive, moderately inactive, moderately active, active and not known) smoking (never, past, current and unknown) and alcohol (continuous) made no appreciable difference to the results so these covariates were not included in the final models.

To improve the comparability of dietary data across participating centres and to correct for measurement error in relative risk estimates, dietary intakes from the questionnaires were calibrated using a fixed-effects linear model in which centre and genderspecific 24 -h recall data from an $8 \%$ random sample of the cohort (Slimani et al, 2002) were regressed on the FFQ intakes (Ferrari et al, 2007).

Separate analyses were conducted for localised and advanced disease, and also for low-grade and high-grade disease. Heterogeneity between these subgroups was tested by fitting stratified Cox models based on competing risks, comparing the risk coefficients and standard errors in the subgroups of interest after excluding cases of uncertain stage and grade as previously described (Smith-Warner et al, 2006). To evaluate whether preclinical disease may have influenced results, additional analyses were conducted after excluding the first 4 years of follow-up. We also examined whether the association between animal foods and risk was modified by age at recruitment $(<60$ and $\geqslant 60$ years). Heterogeneity in the association with prostate cancer risk between 
countries was assessed using $\chi^{2}$ tests. All $P$-values presented are two-tailed and $P$-values below 0.05 were considered statistically significant. Analyses were performed using Stata v. 9 (Stata Corporation, Texas, USA).

\section{RESULTS}

Details of participants from the eight countries are shown in Table 1. After an average of 8.7 years of follow-up, 2727 men were diagnosed with prostate cancer among the 142520 participants included in this study, with a total of 1236265 person-years. The median age at diagnosis of prostate cancer was 66 years (range: 44-95 years). There was an approximate two-fold variation in the calibrated median intake of total meat and meat products among participating countries, and a three- to six-fold variation in the intake of red meat, poultry, milk and milk beverages, cheese and eggs; the median intake of processed meat and yoghurt varied by more than 10 -fold among countries. On the basis of 24 -h recall data, protein intake was largely derived from meat (32\%), cereals $(18 \%)$, cheese $(9 \%)$ and milk (7\%). Overall, $17 \%$ of protein was derived from dairy products, although this varied from $11 \%$ in Spain to $23 \%$ in Sweden. Dietary calcium was largely derived from dairy products $(53 \%)$, with milk, cheese and yoghurt contributing 22,23 and $8 \%$, respectively. Variation in the proportion of calcium derived from dairy foods ranged from $43 \%$ in Germany to $65 \%$ in Sweden. There was a very strong correlation between dairy protein and dairy calcium intake $(r=0.98)$.

Differences in nondietary characteristics at baseline between prostate cancer cases and noncases are shown in Table 2. Cases were older, less likely to be current smokers or physically active, and were more likely to be married than noncases. In Cox regression analyses, being educated to a degree level or higher, and being married or cohabiting, were each associated with a statistically significant increased risk (results not shown) and were therefore included in subsequent models of dietary intake and risk.

Table 3 shows hazard ratios (HRs) for prostate cancer in relation to consumption of meat, fish, dairy foods and eggs, stratified by centre and adjusted for education, marital status, height, weight and energy intake. Overall, there was no association between any of the meat or fish products or eggs and risk. For dairy products, yoghurt intake was associated with an increased risk (the HR for the highest versus the lowest fifth of intake was $1.17,95 \%$ confidence interval $\left.(\mathrm{CI}): 1.04-1.31 ; P_{\text {trend }}=0.02\right)$, but there was no evidence of an association with intakes of milk and milk beverages or cheese.

Total protein intake was nonsignificantly positively associated with increased risk (HR in the highest versus the lowest fifth of intake $=1.17,95 \%$ CI: $\left.0.96-1.44 ; P_{\text {trend }}=0.07\right)($ Figure 1$)$. Protein from dairy foods was significantly associated with an increased risk (HR for the highest versus lowest fifth was $1.22,95 \% \mathrm{CI}$ : $1.07-1.41 ; P_{\text {trend }}=0.02$ ). Protein derived from all animal or all plant foods was not significantly associated with risk. Total dietary calcium intake and calcium intake from dairy foods were also associated with an increased risk (HR for the highest versus the lowest fifth of intake were 1.17, 95\% CI: $1.00-1.35 ; P_{\text {trend }}=0.01$ for total dietary calcium, and 1.18, 95\% CI: $1.03-1.36 ; P_{\text {trend }}=0.02$ for dairy calcium). Calcium intake from nondairy foods was not associated with risk.

Table 4 shows the HRs for prostate cancer associated with consumption of protein and calcium evaluated as continuous variables, before and after calibration. Protein intake from dairy products, total dietary calcium and calcium from dairy products were all associated with a significant increase in risk, which was larger after calibration. An increment of $35 \mathrm{~g} \mathrm{day}^{-1}$ dairy protein

Table 2 Baseline nondietary characteristics of prostate cancer cases and noncases in EPIC

\begin{tabular}{|c|c|c|}
\hline Characteristic & Cases & Noncases \\
\hline Number of subjects & 2727 & 139793 \\
\hline Age at recruitment (years) & $60.3(6.7)$ & $51.5(10.1)$ \\
\hline Height $(\mathrm{cm})^{\mathrm{a}}$ & $174.3(7.0)$ & $174.7(7.3)$ \\
\hline Weight $(\mathrm{kg})^{\mathrm{a}}$ & $80.2(11.4)$ & $80.9(12.0)$ \\
\hline $\mathrm{BMI}\left(\mathrm{kg} \mathrm{m}^{-2}\right)^{\mathrm{a}}$ & $26.4(3.4)$ & $26.5(3.6)$ \\
\hline \multicolumn{3}{|l|}{ Smoking, \% } \\
\hline Never & 33.6 & 32.9 \\
\hline Former & 43.8 & 36.1 \\
\hline Current & 21.5 & 29.6 \\
\hline Unknown & 1.1 & 1.4 \\
\hline \multicolumn{3}{|c|}{ Combined total physical activity, \% } \\
\hline Inactive & 14.6 & 18.5 \\
\hline Moderately inactive & 30.5 & 26.2 \\
\hline Moderately active & 36.5 & 32.5 \\
\hline Active & 6.9 & 12.3 \\
\hline Unknown & 11.5 & 10.5 \\
\hline \multicolumn{3}{|l|}{ Education, \% } \\
\hline Below degree level & 71.1 & 70.8 \\
\hline Degree level & 25.0 & 26.2 \\
\hline Unknown & 3.9 & 3.0 \\
\hline \multicolumn{3}{|l|}{ Marital status, \% } \\
\hline Married & 65.8 & 55.8 \\
\hline Not married & 12.0 & 13.2 \\
\hline Unknown & 22.2 & 31.0 \\
\hline
\end{tabular}

aValues are means (and s.d. in parentheses)

Table I Description of the study cohorts with men participating in the European Prospective Investigation into Cancer and Nutrition (EPIC)

\begin{tabular}{|c|c|c|c|c|c|c|}
\hline Country & $\begin{array}{l}\text { Number of } \\
\text { men }\end{array}$ & $\begin{array}{l}\text { Cases } \\
\text { (nos.) }\end{array}$ & $\begin{array}{l}\text { Localised } \\
\text { (nos.) }\end{array}$ & $\begin{array}{l}\text { Advanced } \\
\text { (nos.) }\end{array}$ & Person-years & $\begin{array}{l}\text { Median age at recruitment } \\
(5 \text { th }-95 \text { th percentile) }\end{array}$ \\
\hline Denmark & 26267 & 368 & 188 & 104 & 198584 & $56(50-64)$ \\
\hline Germany & 21567 & 420 & 240 & 92 & 176902 & $52(4 \mid-63)$ \\
\hline Italy & 14009 & 145 & 27 & 30 & 120984 & $49(38-62)$ \\
\hline The Netherlands & 9782 & 59 & 11 & 29 & 82852 & $43(23-58)$ \\
\hline Spain & 15150 & 206 & 144 & 23 & 156070 & $49(40-63)$ \\
\hline All countries & 142520 & 2727 & 1131 & 541 & 1236265 & $52(33-67)$ \\
\hline
\end{tabular}


Table 3 Multivariate hazard ratios (HRs) and 95\% confidence intervals (Cls) for prostate cancer among 142520 men in the EPIC cohort by fifths of observed intake of meat, fish and dairy foods

Fifth of food intake

\begin{tabular}{|c|c|c|c|c|c|c|c|c|c|c|c|}
\hline Food & \multicolumn{2}{|r|}{$\mathbf{I}$} & \multicolumn{2}{|r|}{2} & \multicolumn{2}{|r|}{3} & \multicolumn{2}{|r|}{4} & \multicolumn{2}{|r|}{5} & \\
\hline $\begin{array}{l}\text { Meat and meat } \\
\text { products }\end{array}$ & 442 & 1.00 (referent) & 601 & $1.08(0.95-1.23)$ & 512 & $0.96(0.84-1.10)$ & 473 & $0.99(0.86-1.15)$ & 413 & $0.97(0.83-1.14)$ & 0.85 \\
\hline Red meat ${ }^{b}$ & 499 & 1.00 (referent) & 602 & $1.03(0.91-1.17)$ & 532 & $1.00(0.88-1.13)$ & 437 & $0.97(0.84-1.12)$ & 371 & $0.96(0.82-1.12)$ & 0.69 \\
\hline Poultry & 738 & 1.00 (referent) & 534 & $1.05(0.93-1.18)$ & 517 & $1.11(0.98-1.25)$ & 471 & $1.07(0.95-1.21)$ & 467 & $1.12(0.98-1.27)$ & 0.06 \\
\hline Fish and fish products & & & & $1.00(0.87-1.14)$ & & $1.09(0.96-1.25)$ & & $1.02(0.90-1.17)$ & & $1.20)$ & 0.56 \\
\hline White fish ${ }^{c}$ & 436 & 1.00 (referent) & 260 & $1.08(0.9 \mid-1.27)$ & 319 & $0.97(0.83-1.13)$ & 452 & $0.99(0.86-1.14)$ & 554 & $1.03(0.90-1.18)$ & 0.90 \\
\hline Fatty fish & 579 & 1.00 (referent) & 382 & $1.04(0.91-1.19)$ & 562 & $1.05(0.94-1.19)$ & 538 & $1.03(0.92-1.17)$ & 666 & $1.07(0.95-1.21)$ & 0.95 \\
\hline $\begin{array}{l}\text { Milk and milk } \\
\text { beverages }\end{array}$ & 470 & 1.00 (referent) & 489 & $1.00(0.88-1.14)$ & 517 & $0.98(0.86-1.11)$ & 594 & $0.97(0.85-1.10)$ & 657 & $1.01(0.89-1.16)$ & 0.23 \\
\hline Yoghurt & 684 & 1.00 (referent) & 351 & $0.91(0.79-1.06)$ & 434 & $1.08(0.94-1.23)$ & 516 & $1.09(0.96-1.23)$ & 742 & $1.17(1.04-1.31)$ & 0.02 \\
\hline
\end{tabular}

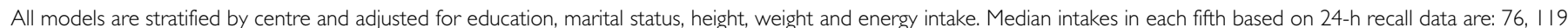

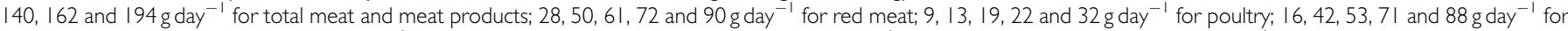

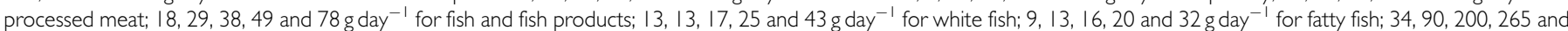
$466 \mathrm{~g} \mathrm{day}^{-1}$ for milk and milk beverages; 12, 10, 26, 59 and I $35 \mathrm{~g}$ day $^{-1}$ for yoghurt (also includes fromage blanc and petits suisses); I5, 28, 35, 40 and 57 g day ${ }^{-1}$ for cheese; and 9 ,

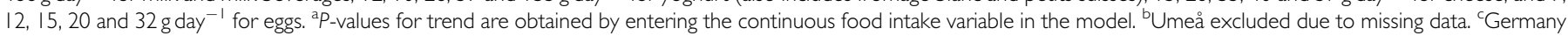
and Umeå excluded due to missing data.

was associated with an HR of 1.32 (95\% CI: $1.01-1.72$; $\left.P_{\text {trend }}=0.04\right)$ and increments of $0.3 \mathrm{~g} \mathrm{day}^{-1}$ of total calcium and dairy calcium were associated with HRs of 1.09 (95\% CI: $1.01-1.16$; $\left.P_{\text {trend }}=0.02\right)$ and $1.07 \quad\left(95 \% \quad\right.$ CI: $\left.1.00-1.14 ; \quad P_{\text {trend }}=0.04\right)$, respectively.

The associations between calibrated estimates of protein and calcium intake and risk according to stage and grade of disease are shown in Table 5. Risk estimates for most nutrients were slightly higher for localised disease $(n=1131)$ than advanced disease $(n=541)$, but none reached statistical significance. No nutrients were associated with low-grade disease, but intakes of dairy protein, total dietary calcium and dairy calcium were significantly associated with an increased risk of high-grade disease (HRs of 1.76, 95\% CI: $1.06-2.95 ; P_{\text {trend }}=0.03$ for an increment increase of $35 \mathrm{~g} \mathrm{day}^{-1}$ dairy protein; and $1.19,95 \% \mathrm{CI}$ : $1.04-1.37 ; P_{\text {trend }}=0.01$ and $1.16,95 \%$ CI: $1.03-1.32 ; P_{\text {trend }}=0.02$ for an increment increase of $0.3 \mathrm{~g} \mathrm{day}^{-1}$ of total calcium and dairy calcium, respectively). However, the tests for heterogeneity between the risk estimates for low-grade and high-grade disease were not statistically significant for any of these nutrients.

The associations between nutrients and prostate cancer risk were similar below the age of 60 years at recruitment $(n=1222)$ and at older ages $(n=1505)$, although some significant associations were found for calibrated intakes among men below the age of 60 years at recruitment $(\mathrm{HR}=1.43,95 \% \mathrm{CI}$ : $1.02-2.03$, for $35 \mathrm{~g} \mathrm{day}^{-1}$ of dairy protein, $\mathrm{HR}=1.10,95 \% \mathrm{CI}$ : $1.01-1.20$, for $0.3 \mathrm{~g} \mathrm{day}^{-1}$ for both total and dairy calcium). To examine whether cancers diagnosed soon after recruitment may have influenced the results, the analyses were repeated after excluding the first 4 years of follow-up, leaving 2010 cases and 134944 noncases, but they did not materially change (results not shown). There was no evidence of heterogeneity between countries in the association of protein or calcium intake with risk of overall prostate cancer (results not shown).

\section{DISCUSSION}

In this prospective study of 2727 cases of prostate cancer, the consumption of protein and calcium derived from dairy foods were significantly positively associated with risk. Strengths of the EPIC study are its prospective design, the large number of prostate cancer cases and the wide range of animal food intakes. We were also able to consider other possible risk factors such as education, marital status, alcohol intake, height, weight, energy intake, smoking and physical activity. Data on PSA use in the EPIC cohort are not available, but the annual rates of PSA testing in middle aged men within some of the participating countries suggest relatively low rates, of $6 \%$ in England and Wales, $7 \%$ in the Netherlands, $9 \%$ in Spain and $16 \%$ in Italy, compared with approximately $38 \%$ in white Americans (Etzioni et al, 2002; Paez et al, 2002; Otto et al, 2003; D'Ambrosio et al, 2004; Melia et al, 2004).

Our results are compatible with the hypothesis that a high intake of dairy protein is associated with increased prostate cancer risk (Gao et al, 2005). Although we found no association with milk intake per se, protein and calcium intake derived from dairy foods, and also yoghurt intake, were significantly associated with increased risk. This apparent discrepancy may, in part, be because dairy protein and calcium are derived from a combination of dairy products, which on their own only exhibit a weak association with risk.

It has been hypothesised that the high protein content of dairy products may increase risk by increasing circulating levels of IGFI, as shown in several cross-sectional studies (Holmes et al, 2002; Giovannucci et al, 2003; Heald et al, 2003; Larsson et al, 2005; Norat et al, 2007) and some intervention trials (Heaney et al, 1999; Hoppe et al, 2004). Vegan men and women (who consume no dairy or other animal products) have significantly lower serum IGF-I levels than both lacto-ovo vegetarians and meat eaters (Allen $e t a l$, 2000,2002 ), which may be due to their lower intake of essential amino acids (Allen et al, 2002). Intervention studies have 


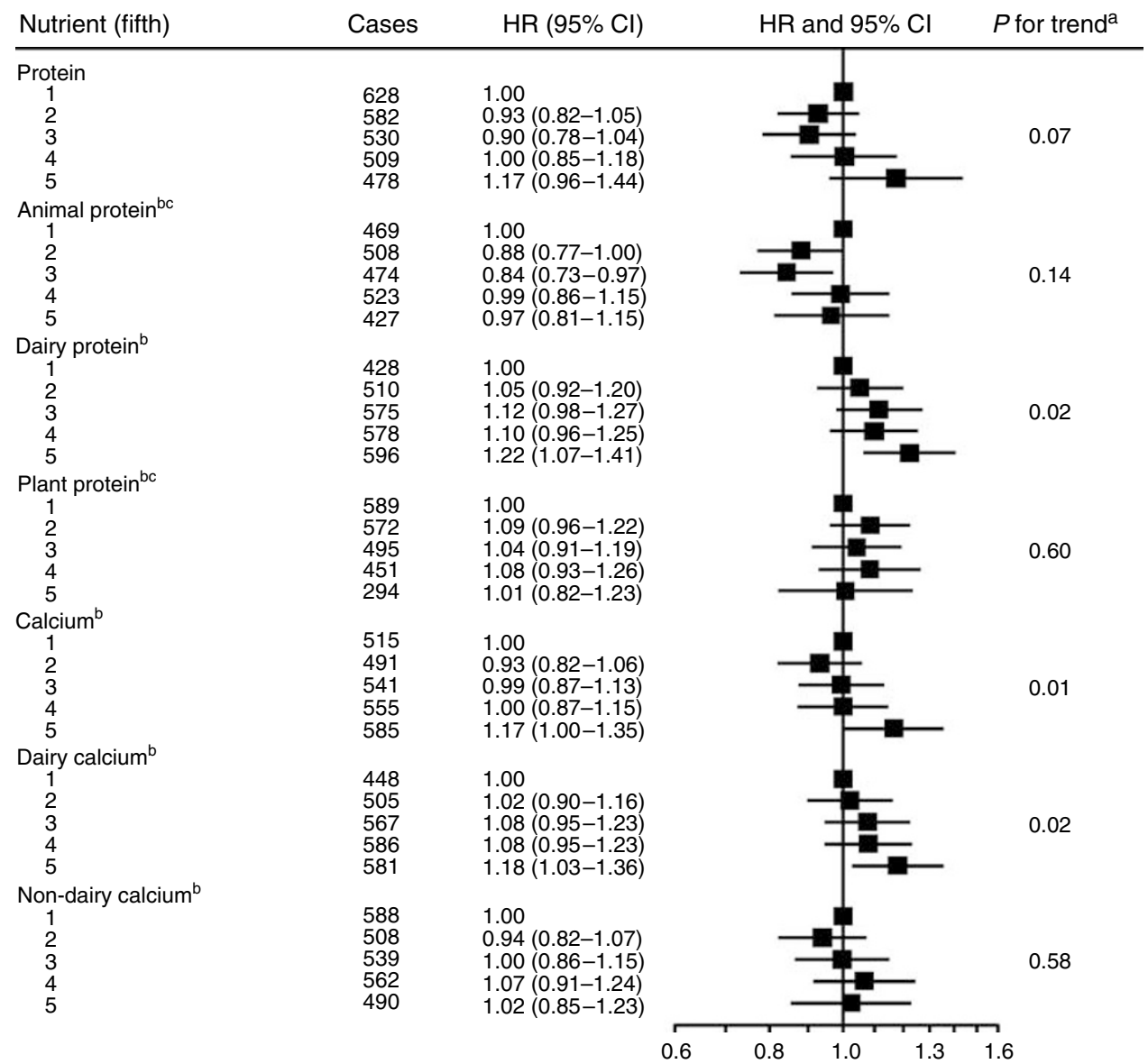

Figure I Multivariate HRs and $95 \% \mathrm{Cls}$ for prostate cancer by quintile of observed intake of protein and calcium. All models are stratified by centre and adjusted for education, marital status, height, weight and energy intake. Mean intakes in each quintile based on 24-h recall data are: 80, 90, 98, 105 and $121 \mathrm{~g} \mathrm{day}^{-1}$ for protein; 47, 59, 64, 69 and $80 \mathrm{~g} \mathrm{day}^{-1}$ for animal protein; 10, 14, 17, 21 and $27 \mathrm{~g} \mathrm{day}^{-1}$ for dairy protein; 29, 33, 36, 38 and $47 \mathrm{~g}$ day ${ }^{-1}$ for plant protein; $0.78,0.92,1.01,1.10$ and $1.32 \mathrm{~g} \mathrm{day}^{-1}$ for total calcium; $0.30,0.44,0.56,0.68$ and $0.88 \mathrm{~g} \mathrm{day}^{-1}$ for dairy calcium; and $0.38,0.42,0.45,1.8$ and $5.5 \mathrm{~g} \mathrm{day}^{-1}$ for nondairy calcium. ${ }^{\mathrm{a}} \mathrm{P}$-values for trend are obtained by entering the continuous variable in the model. ${ }^{\mathrm{b}} \mathrm{Greece}$ excluded. ${ }^{\mathrm{C}} \mathrm{Umea}$ excluded.

Table 4 Multivariate hazard ratios (HRs) and 95\% confidence intervals (Cls) for prostate cancer among I42520 men in the EPIC cohort for specified increments in observed (uncalibrated) and calibrated intakes of protein and calcium

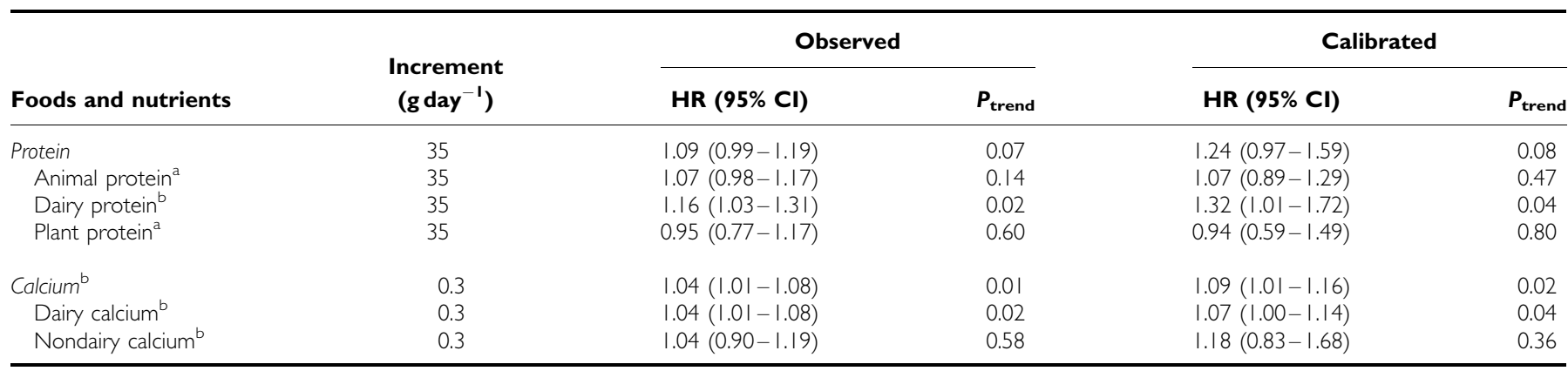

All models are stratified by centre and adjusted for education, marital status, height, weight and energy intake. ${ }^{\mathrm{a}} \mathrm{Greece}$ and Umeå excluded due to missing data. ${ }^{\mathrm{b}} \mathrm{Greece}$ excluded due to missing data.

also shown that protein restriction can lower IGF-I levels in both animals (Miura et al, 1992; Takenaka et al, 2000; Katsumata et al, 2002) and humans (Smith et al, 1995), and that the increases in IGF-I levels following re-feeding are strongly related to the essential amino-acid component of the diet (Clemmons et al, 1985). The effects of protein and especially dairy protein on IGF-I could be important, because high serum IGF-I levels have been associated with a moderately increased risk of prostate cancer in several large-scale prospective studies including EPIC (Renehan et al, 2004; Allen et al, 2007). However, few studies have reported on protein intake in relation to risk (Severson et al, 1989; Schuurman et al, 1999; Chan et al, 2000), and, to our knowledge, this is the first study to examine specifically the association of dairy protein in risk. 
Table 5 Multivariate hazard ratios (HRs) and 95\% confidence intervals (Cls) by stage and grade of prostate cancer for specified increments in calibrated intakes of protein and calcium in EPIC

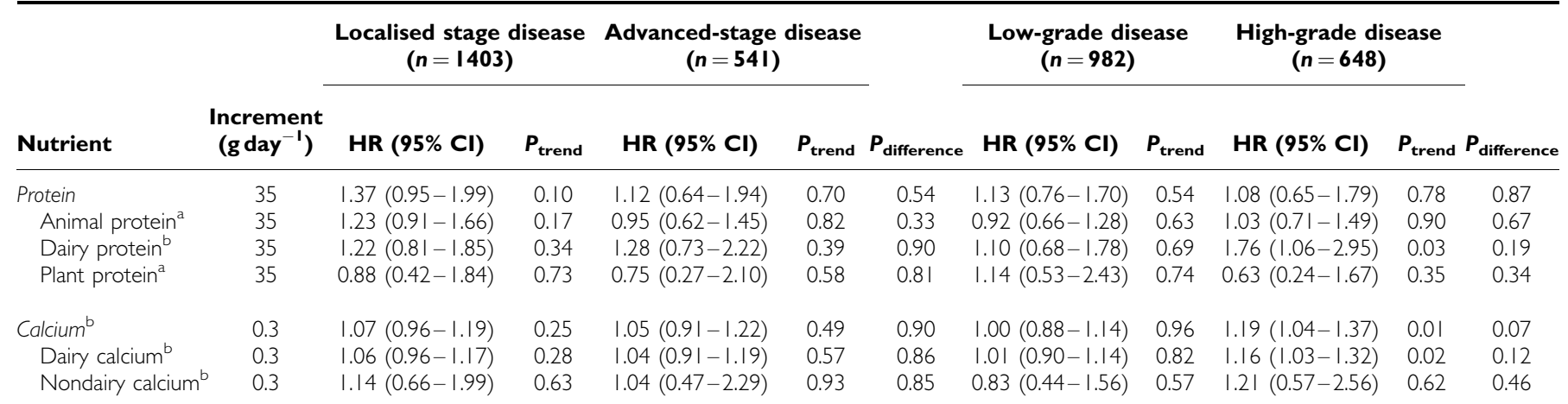

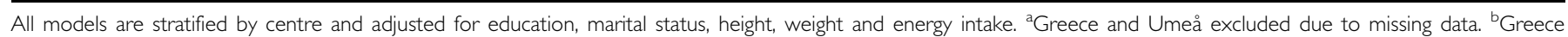
excluded due to missing data.

An alternative hypothesis is that dairy products may increase prostate cancer risk via their high calcium content, and our finding of a positive association with calcium intake is consistent with some (Chan et al, 2001; Gao et al, 2005; Tseng et al, 2005; Giovannucci et al, 2006; Kesse et al, 2006; Ahn et al, 2007; Mitrou et al, 2007), but not all, prospective studies (Koh et al, 2006; Severi et al, 2006; Rohrmann et al, 2007). It has been suggested that a high calcium intake may increase risk by suppressing the synthesis of 1,25-dihydroxyvitamin $\mathrm{D}$, which has an antitumour effect on human prostatic cells in vitro (Giovannucci, 1998). However, a randomised controlled trial showed that, although long-term calcium supplementation ( $1.2 \mathrm{~g}$ calcium per day) slightly reduced serum 1,25-dihydroxyvitamin D concentrations, it was not associated with increased risk, although this trial was too small to exclude a moderate effect (upper CI in treated group 1.32; Baron et al, 2005). In addition, the evidence that circulating levels of either 1,25-dihydroxyvitamin D or its precursor 25-dihydroxyvitamin D are inversely related to risk is inconsistent (Giovannucci, 2005). Overall, the evidence that a high calcium intake affects risk through mechanisms related to vitamin $\mathrm{D}$ production appears limited. It is possible that the association seen with dairy calcium intake may be due to its high correlation with other aspects of dairy foods, particularly protein, although it is difficult to separate out their independent effects. Further, although the intake of nondairy calcium was low, the finding that it was not associated with risk suggests that another component of dairy foods may be of greater aetiological relevance.

Some studies have suggested that the associations with dairy foods and calcium intake are stronger for aggressive disease (Gao et al, 2005; Giovannucci et al, 2006). In the current study, although these associations were slightly stronger for high-grade disease and for men recruited before the age of 60 years, the differences between the groups were not significant, and there were no comparable differences between localised and advanced-stage disease. Several previous studies have found that risk is particularly elevated in men with a total calcium intake (i.e., diet plus supplement intake) above $2 \mathrm{~g} \mathrm{day}^{-1}$ (Rodriguez et al, 2003; Giovannucci et al, 2006; Ahn et al, 2007; Mitrou et al, 2007). However, we had no information on supplement use and although the present study found a significantly elevated risk in the top fifth of dietary intake, the mean intake of this category, based on 24-h recall data, was $1.3 \mathrm{~g} \mathrm{day}^{-1}$; less than $1 \%$ of the cohort had a dietary calcium intake of $2 \mathrm{~g} \mathrm{day}^{-1}$ or more. As such, we had limited power to assess whether very high calcium intake is associated with increased risk.

Our finding that total meat or red meat intake is not associated with prostate cancer risk is consistent with most previous prospective studies (Snowdon, 1988; Mills et al, 1989; Hsing et al, 1990; Chan et al, 2000; Allen et al, 2004; Cross et al, 2005; Rohrmann et al, 2007), although some found positive associations with red meat (Michaud et al, 2001), hamburgers (Veierod et al, 1997), beef (Le Marchand et al, 1994) or cooked processed meat (Rodriguez et al, 2006) for either total or advanced prostate cancer. For fish, our results, which are based on a wide range of intake, provide no evidence that intake is associated with risk, and is consistent with most previous studies (Severson et al, 1989; Hsing et al, 1990; Le Marchand et al, 1994; Gronberg et al, 1996; Schuurman et al, 1999), although some have reported a negative (Terry et al, 2001; Augustsson et al, 2003) or positive association (Mills et al, 1989; Allen et al, 2004).

Our study has some limitations. As in other large epidemiological studies, dietary intake is estimated using relatively simple dietary questionnaires that are subject to measurement errors leading to attenuated risk estimates. Nonetheless, the questionnaires in all EPIC centres were validated, and dietary intakes were calibrated with measures from a standardised 24 -h diet recall method.

In conclusion, the results from this large prospective study are consistent with the hypothesis that a high intake of protein or calcium from dairy products may increase prostate cancer risk.

\section{ACKNOWLEDGEMENTS}

We thank all the participants in EPIC for their invaluable contribution to the study, and also Bertrand Hémon and colleagues at IARC for their expertise in data handling. This study was sponsored by grants from Cancer Research UK; Europe Against Cancer Programme of the European Commission (SANCO); German Cancer Aid; German Cancer Research Center; German Federal Ministry of Education and Research; Danish Cancer Society; Health Research Fund (FIS) of the Spanish Ministry of Health; ISCIII Red de Centros RCESP C03/09, Spain; the participating regional governments and institutions of Spain; Medical Research Council, UK; the Stroke Association, UK; British Heart Foundation; Department of Health, UK; Food Standards Agency, UK; Greek Ministry of Health; Greek Ministry of Education; Italian Association for Research on Cancer; Italian National Research Council; Dutch Ministry of Public Health, Welfare and Sports; Dutch Ministry of Health; Dutch Prevention Funds; LK Research Funds; Dutch ZON (Zorg Onderzoek Nederland); World Cancer Research Fund (WCRF); Swedish Cancer Society; Swedish Scientific Council; and Regional Government of Skane, Sweden. The sponsors had no role in the study design, data collection, analysis, interpretation of results or writing of the paper. 


\section{REFERENCES}

Ahn J, Albanes D, Peters U, Schatzkin A, Lim U, Freedman M, Chatterjee N, Andriole GL, Leitzmann MF, Hayes RB (2007) Dairy products, calcium intake, and risk of prostate cancer in the Prostate, Lung, Colorectal, and Ovarian Cancer Screening Trial. Cancer Epidemiol Biomark Prev 16: $2623-2630$

Allen NE, Appleby PN, Davey GK, Kaaks R, Rinaldi S, Key TJ (2002) The associations of diet with serum insulin-like growth factor-I and its main binding proteins in 292 women meat-eaters, vegetarians and vegans. Cancer Epidemiol Biomark Prev 11: 1441 - 1448

Allen NE, Appleby PN, Davey GK, Key TJ (2000) Hormones and diet: low insulin-like growth factor-I but normal bioavailable androgens in vegan men. Br J Cancer 83: $95-97$

Allen NE, Key TJ, Appleby PN, Travis RC, Roddam AW, Rinaldi S, Egevad L, Rohrmann S, Linseisen J, Pischon T, Boeing H, Johnsen NF, Tjonneland A, Gronbaek H, Overvad K, Kiemeney L, Buenode-Mesquita B, Bingham S, Khaw KT, Tumino R, Berrino F, Mattiello A, Sacerdote C, Palli D, Quiros JR, Ardanaz E, Navarro C, Larranaga N, Gonzalez C, Sanchez-Perez MJ, Trichopoulou A, Travezea C, Trichopolos D, Jenab M, Ferrari P, Riboli E, Kaaks R (2007) Serum IGF-I and IGFBP-3 concentrations and prostate cancer risk: results from the European Prospective Investigation into Cancer and Nutrition (EPIC). Cancer Epidemiol Biomark Prev 16: $1121-1127$

Allen NE, Sauvaget C, Roddam AW, Appleby P, Nagano J, Suzuki G, Key TJ, Koyama K (2004) A prospective study of diet and prostate cancer in Japanese men. Cancer Causes Control 15: 911 - 920

Augustsson K, Michaud DS, Rimm EB, Leitzmann MF, Stampfer MJ, Willett WC, Giovannucci E (2003) A prospective study of intake of fish and marine fatty acids and prostate cancer. Cancer Epidemiol Biomark Prev 12: $64-67$

Baron JA, Beach M, Wallace K, Grau MV, Sandler RS, Mandel JS, Heber D, Greenberg ER (2005) Risk of prostate cancer in a randomized clinical trial of calcium supplementation. Cancer Epidemiol Biomark Prev 14: $586-589$

Chan JM, Pietinen P, Virtanen M, Malila N, Tangrea J, Albanes D, Virtamo J (2000) Diet and prostate cancer risk in a cohort of smokers, with a specific focus on calcium and phosphorus (Finland). Cancer Causes Control 11: $859-867$

Chan JM, Stampfer MJ, Ma J, Gann PH, Gaziano JM, Giovannucci EL (2001) Dairy products, calcium, and prostate cancer risk in the Physicians' Health Study. Am J Clin Nutr 74: 549-554

Clemmons DR, Seek MM, Underwood LE (1985) Supplemental essential amino acids augment the somatomedin-C/insulin-like growth factor-I response to refeeding after fasting. Metabolism 34: $391-395$

Colli JL, Colli A (2006) International comparisons of prostate cancer mortality rates with dietary practices and sunlight levels. Urol Oncol 24: $184-194$

Cross AJ, Peters U, Kirsh VA, Andriole GL, Reding D, Hayes RB, Sinha R (2005) A prospective study of meat and meat mutagens and prostate cancer risk. Cancer Res 65: $11779-11784$

D’Ambrosio G, Samani F, Cancian M, De Mola C (2004) Practice of opportunistic prostate-specific antigen screening in Italy: data from the Health Search database. Eur J Cancer Prev 13: 383-386

Etzioni R, Berry KM, Legler JM, Shaw P (2002) Prostate-specific antigen testing in black and white men: an analysis of medicare claims from 1991 - 1998. Urology 59: 251-255

Ferrari P, Day NE, Boshuizen HC, Roddam AW, Hoffmann K, Thiebaut A, Pera G, Overvad K, Lund E, Trichopoulou A, Tumino R, Gullberg B, Norat T, Slimani N, Kaaks R, Riboli E (2007) The evaluation of the diet/disease relation in the EPIC study: considerations for the calibration and the disease models. Int $J$ Epidemiol (in press). doi:10.1093/ije/Dym242

Ferrari P, Slimani N, Ciampi A, Trichopoulou A, Naska A, Lauria C, Veglia F, Bueno-de-Mesquita HB, Ocke MC, Brustad M, Braaten T, Jose TM, Amiano P, Mattisson I, Johansson G, Welch A, Davey G, Overvad K, Tjonneland A, Clavel-Chapelon F, Thiebaut A, Linseisen J, Boeing H, Hemon B, Riboli E (2002) Evaluation of under- and overreporting of energy intake in the 24-hour diet recalls in the European Prospective Investigation into Cancer and Nutrition (EPIC). Public Health Nutr 5: 1329-1345

Ganmaa D, Li XM, Wang J, Qin LQ, Wang PY, Sato A (2002) Incidence and mortality of testicular and prostatic cancers in relation to world dietary practices. Int J Cancer 98: $262-267$
Gao X, LaValley MP, Tucker KL (2005) Prospective studies of dairy product and calcium intakes and prostate cancer risk: a meta-analysis. J Natl Cancer Inst 97: 1768-1777

Giovannucci E (1998) Dietary influences of $1,25(\mathrm{OH}) 2$ vitamin D in relation to prostate cancer: a hypothesis. Cancer Causes Control 9: 567-582

Giovannucci E (2005) The epidemiology of vitamin D and cancer incidence and mortality: a review (United States). Cancer Causes Control 16: 83-95

Giovannucci E, Liu Y, Stampfer MJ, Willett WC (2006) A prospective study of calcium intake and incident and fatal prostate cancer. Cancer Epidemiol Biomark Prev 15: $203-210$

Giovannucci E, Pollak M, Liu Y, Platz EA, Majeed N, Rimm EB, Willett WC (2003) Nutritional predictors of insulin-like growth factor I and their relationships to cancer in men. Cancer Epidemiol Biomark Prev 12: $84-89$

Gronberg H, Damber L, Damber JE (1996) Total food consumption and body mass index in relation to prostate cancer risk: a case-control study in Sweden with prospectively collected exposure data. J Urol 155: $969-$ 974

Heald AH, Cade JE, Cruickshank JK, Anderson S, White A, Gibson JM (2003) The influence of dietary intake on the insulin-like growth factor (IGF) system across three ethnic groups: a population-based study. Public Health Nutr 6: $175-180$

Heaney RP, McCarron DA, Dawson-Hughes B, Oparil S, Berga SL, Stern JS, Barr SI, Rosen CJ (1999) Dietary changes favorably affect bone remodeling in older adults. J Am Diet Assoc 99: 1228-1233

Holmes MD, Pollak MN, Willett WC, Hankinson SE (2002) Dietary correlates of plasma insulin-like growth factor I and insulin-like growth factor binding protein 3 concentrations. Cancer Epidemiol Biomark Prev 11: $852-861$

Hoppe C, Molgaard C, Juul A, Michaelsen KF (2004) High intakes of skimmed milk, but not meat, increase serum IGF-I and IGFBP-3 in eightyear-old boys. Eur J Clin Nutr 58: 1211-1216

Hsing AW, McLaughlin JK, Schuman LM, Bjelke E, Gridley G, Wacholder S, Chien HT, Blot WJ (1990) Diet, tobacco use, and fatal prostate cancer: results from the Lutheran Brotherhood Cohort Study. Cancer Res 50: $6836-6840$

Katsumata M, Kawakami S, Kaji Y, Takada R, Dauncey MJ (2002) Differential regulation of porcine hepatic IGF-I mRNA expression and plasma IGF-I concentration by a low lysine diet. J Nutr 132: 688-692

Kesse E, Bertrais S, Astorg P, Jaouen A, Arnault N, Galan P, Hercberg S (2006) Dairy products, calcium and phosphorus intake, and the risk of prostate cancer: results of the French prospective SU.VI.MAX (Supplementation en Vitamines et Mineraux Antioxydants) study. Br J Nutr 95: $539-545$

Koh KA, Sesso HD, Paffenbarger RSJ, Lee IM (2006) Dairy products, calcium and prostate cancer risk. $\mathrm{Br}$ J Cancer 95: $1582-1585$

Larsson SC, Wolk K, Brismar K, Wolk A (2005) Association of diet with serum insulin-like growth factor I in middle-aged and elderly men. Am J Clin Nutr 81: 1163-1167

Le Marchand L, Kolonel LN, Wilkens LR, Myers BC, Hirohata T (1994) Animal fat consumption and prostate cancer: a prospective study in Hawaii. Epidemiology 5: 276-282

Melia J, Moss S, Johns L (2004) Rates of prostate-specific antigen testing in general practice in England and Wales in asymptomatic and symptomatic patients: a cross-sectional study. BJU Int 94: $51-56$

Michaud DS, Augustsson K, Rimm EB, Stampfer MJ, Willet WC, Giovannucci E (2001) A prospective study on intake of animal products and risk of prostate cancer. Cancer Causes Control 12: 557-567

Mills PK, Beeson WL, Phillips RL, Fraser GE (1989) Cohort study of diet, lifestyle, and prostate cancer in Adventist men. Cancer 64: 598-604

Mitrou PN, Albanes D, Weinstein SJ, Pietinen P, Taylor PR, Virtamo J, Leitzmann MF (2007) A prospective study of dietary calcium, dairy products and prostate cancer risk (Finland). Int J Cancer 120: 2466-2473

Miura Y, Kato H, Noguchi T (1992) Effect of dietary proteins on insulin-like growth factor-1 (IGF-1) messenger ribonucleic acid content in rat liver. Br J Nutr 67: $257-265$

Norat T, Dossus L, Rinaldi S, Overvad K, Gronbaek H, Tjonneland A, Olsen A, Clavel-Chapelon F, Boutron-Ruault MC, Boeing $\mathrm{H}$, Lahmann PH, Linseisen J, Nagel G, Trichopoulou A, Trichopoulos D, Kalapothaki V, Sieri S, Palli D, Panico S, Tumino R, Sacerdote C, Bueno-de-Mesquita HB, Peeters PH, van Gils CH, Agudo A, Amiano P, Ardanoz E, Martinez C, Quiros R, Tormo MJ, Bingham S, Key TJ, Allen NE, Ferrari P, Slimani N, Riboli E, Kaaks R (2007) Diet, serum 
insulin-like growth factor-I and IGF-binding protein-3 in European women. Eur J Clin Nutr 61: 91-98

Otto SJ, van der Cruijsen IW, Liem MK, Korfage IJ, Lous JJ, Schroder FH, De Koning HJ (2003) Effective PSA contamination in the Rotterdam section of the European Randomized Study of Screening for Prostate Cancer. Int J Cancer 105: 394-399

Paez A, Lujan M, Llanes L, Romero I, de la Cal MA, Miravalles E, Berenguer A (2002) PSA-use in a Spanish industrial area. Eur Urol 41: 162-166

Renehan AG, Zwahlen M, Minder C, O'Dwyer ST, Shalet SM, Egger M (2004) Insulin-like growth factor (IGF)-I, IGF binding protein-3, and cancer risk: systematic review and meta-regression analysis. Lancet 363: $1346-1353$

Riboli E, Hunt KJ, Slimani N, Ferrari P, Norat T, Fahey M, Charrondiere UR, Hemon B, Casagrande C, Vignat J, Overvad K, Tjonneland A, Clavel-Chapelon F, Thiebaut A, Wahrendorf J, Boeing H, Trichopoulos D, Trichopoulou A, Vineis P, Palli D, Bueno-de-Mesquita HB, Peeters PH, Lund E, Engeset D, Gonzalez CA, Barricarte A, Berglund G, Hallmans G, Day NE, Key TJ, Kaaks R, Saracci R (2002) European Prospective Investigation into Cancer and Nutrition (EPIC): study populations and data collection. Public Health Nutr 5: 1113-1124

Rodriguez C, McCullough ML, Mondul AM, Jacobs EJ, Chao A, Patel AV, Thun MJ, Calle EE (2006) Meat consumption among Black and White men and risk of prostate cancer in the Cancer Prevention Study II Nutrition Cohort. Cancer Epidemiol Biomark Prev 15: 211 - 216

Rodriguez C, McCullough ML, Mondul AM, Jacobs EJ, FakhrabadiShokoohi D, Giovannucci EL, Thun MJ, Calle EE (2003) Calcium, dairy products, and risk of prostate cancer in a prospective cohort of United States men. Cancer Epidemiol Biomark Prev 12: 597-603

Rohrmann S, Platz EA, Kavanaugh CJ, Thuita L, Hoffman SC, Helzlsouer KJ (2007) Meat and dairy consumption and subsequent risk of prostate cancer in a US cohort study. Cancer Causes Control 18: 41-50

Sato T (1963) Chronic diseases suspected to arise through the enhanced activity of growth hormone by excessive intake of animal protein. IV. The cancer and the hypertrophy of the prostate. Bull Inst Public Health 12: $222-228$

Schuurman AG, van den Brandt PA, Dorant E, Goldbohm RA (1999) Animal products, calcium and protein and prostate cancer risk in the Netherlands Cohort Study. Br J Cancer 80: 1107-1113

Severi G, English DR, Hopper JL, Giles GG (2006) Re: Prospective studies of dairy product and calcium intakes and prostate cancer risk: a metaanalysis. J Natl Cancer Inst 98: 794-795
Severson RK, Nomura AM, Grove JS, Stemmermann GN (1989) A prospective study of demographics, diet, and prostate cancer among men of Japanese ancestry in Hawaii. Cancer Res 49: 1857-1860

Slimani N, Kaaks R, Ferrari P, Casagrande C, Clavel-Chapelon F, Lotze G, Kroke A, Trichopoulos D, Trichopoulou A, Lauria C, Bellegotti M, Ocke MC, Peeters PH, Engeset D, Lund E, Agudo A, Larranaga N, Mattisson I, Andren C, Johansson I, Davey G, Welch AA, Overvad K, Tjonneland A, Van Staveren WA, Saracci R, Riboli E (2002) European Prospective Investigation into Cancer and Nutrition (EPIC) calibration study: rationale, design and population characteristics. Public Health Nutr 5: $1125-1145$

Smith WI, Underwood LE, Clemmons DR (1995) Effects of caloric or protein restriction on insulin-like growth factor-I (IGF-I) and IGFbinding proteins in children and adults. J Clin Endocrinol Metab 80: $443-449$

Smith-Warner SA, Spiegelman D, Ritz J, Albanes D, Beeson WL, Bernstein L, Berrino F, van den Brandt PA, Buring JE, Cho E, Colditz GA, Folsom AR, Freudenheim JL, Giovannucci E, Goldbohm RA, Graham S, Harnack L, Horn-Ross PL, Krogh V, Leitzmann MF, McCullough ML, Miller AB, Rodriguez C, Rohan TE, Schatzkin A, Shore R, Virtanen M, Willett WC, Wolk A, Zeleniuch-Jacquotte A, Zhang SM, Hunter DJ (2006) Methods for pooling results of epidemiologic studies: the Pooling Project of Prospective Studies of Diet and Cancer. Am J Epidemiol 163: $1053-1064$

Snowdon DA (1988) Animal product consumption and mortality because of all causes combined, coronary heart disease, stroke, diabetes, and cancer in Seventh-day Adventists. Am J Clin Nutr 48: $739-748$

Takenaka A, Oki N, Takahashi SI, Noguchi T (2000) Dietary restriction of single essential amino acids reduces plasma insulin-like growth factor-I (IGF-I) but does not affect plasma IGF-binding protein-1 in rats. J Nutr 130: $2910-2914$

Terry P, Lichtenstein P, Feychting M, Ahlbom A, Wolk A (2001) Fatty fish consumption and risk of prostate cancer. Lancet 357: 1764-1766

Tseng M, Breslow RA, Graubard BI, Ziegler RG (2005) Dairy, calcium, and vitamin D intakes and prostate cancer risk in the National Health and Nutrition Examination Epidemiologic Follow-up Study cohort. Am J Clin Nutr 81: $1147-1154$

Veierod MB, Laake P, Thelle DS (1997) Dietary fat intake and risk of prostate cancer: a prospective study of 25,708 Norwegian men. Int $J$ Cancer 73: 634-638 